\title{
HEDGING TRANSACTION AND ECONOMIC EXPOSURE: A SOLUTION FOR PT PURA DAYA PRIMA
}

\author{
Ita Puspitasari Mulyono ${ }^{1}$, Michael Suhardianto ${ }^{2} \&$ Raymundus Parulian Sihotang ${ }^{3}$
}

\begin{abstract}
Many companies use more than one currency in doing business, which make them being exposed to exchange rate risk fluctuation. Accordingly, the Company's financial manager needs to understand how to measure the risk exposure in order to determine when and how to protect the company from the risk.

PT Pura Daya Prima (PDP) is one of that companies which has long been concerned on how to mitigate its economic and transaction exposure.

The purpose of this project is to help the company mitigate its risk exposure and find the best hedging technique or other mitigation strategy to minimize their risk.

The result of the project is to determine the most favorable hedging policy and the best way to implement the financial instruments or products available in the market or simulated. It is expected that PT Pura Daya Prima would be able to quickly execute hedging techniques in order to prevent financial loss due to foreign exchange exposure.
\end{abstract}

Keywords: risk, exposure, exchange rate, IPP, hedging, derivatives

\footnotetext{
${ }^{1,2}$ BINUS BUSINESS SCHOOL, BINUS UNIVERSITY, JWC Campus, Jl. Hang Lekir I No. 6, Kebayoran Baru, South Jakarta 12120, yovitavinsensiaita@yahoo.com

3 Senior Manager BP MIGAS, psihotang@bpmigas.com
} 


\section{INTRODUCTION}

Basically, the majority of multinational companies use more than one currency in doing business, which makes them being exposed by exchange rate risk, namely fluctuating rate due to inflation and interest rate. Concerning their operation, their financial managers should understand how to measure/read risk exposure encountered by the company, so that they can determine when and how to protect the company from the risk. They will apply international financial management science, covering investing and financial decisions, which eventually aims at increasing shareholders' asset or company's value.

In international finance science/field, there are many financial instruments that can be applied or practiced to reduce or mitigate the risk resulting from currency exchange rate fluctuation during a certain period. This rate fluctuation will clearly change foreign and local currency value, so that there will be variance to actual expenses and actual revenue of the company, and eventually affect the company's projected cash flow in this period. Some companies apply currency derivatives, such as forward, future, option, swap and others, to hedge their exposure to the fluctuating foreign currency exchange rate risk.

In its operation, PDP is exposed to currency rate exposure, especially transaction and economic exposure. This makes PDP quite difficult to maintain stability of its revenue and cost. Based on the Power Purchase Agreement (PPA) no. 182.PJ/061/WS2JB/2004 and no. 002/SPJ.PDP/0705 between PT PLN (Persero) WS2JB and PDP, power monthly tariff will be paid to PDP in Indonesian Rupiah (IDR).

The risk exposure encountered by PDP is USD/IDR rate when the invoice is received and USD/IDR rate at that time (spot rate), when PDP has to pay to Pertamina. Another expense of PDP that is exposed to foreign currency exchange rate fluctuation risk is maintenance periodic cost that must be paid quarterly to Turbomach in accordance with the Full Maintenance Contract.

Based on the abovementioned matter, we choose PDP for analysis in our Group Field Project and we give this thesis a title of "Hedging Transaction and Economic Exposure: A Solution for PT Pura Daya Prima"

\section{PROBLEM IDENTIFICATION}

Based on the previous background paragrahps, we can conclude that there are several problems that PDP is currently facing related to financial risk. They include:

a.What $\operatorname{risk}(\mathrm{s})$ is the company exposed to?

b. How much loss has the company suffered for the last couple years due to their currency risk exposure?

c.What is the most favorable hedging policy in order to mitigate those risks?

d. What is the best way to implement the financial instruments or products that are available in the market?

e.What is the strength and weakness of the hedging policy which about to be implemented? 


\section{THEORY FOUNDATION}

\section{Definition and Foreign Exchange Quotation}

According to Eiteman et al.(1995), a foreign-exchange rate (forex rate or FX rate) is the price of one currency expressed in terms of another currency. A foreign exchange quotation is a statement of willingness to buy or sell at an announced rate.

\section{Related Theory of Foreign Exchange}

There are several famous theories concerning currency exchange rate from Levi (1990). They include Interest Rate Parity Theorem (IRPT), Purchasing Power Parity Theorem (PPPT), and Monetary Approach to Balance of Payment or Exchange Rate (MAER). The following description only concerns 2 first theories above, because MAER is based on PPRT.

\section{A. Interest Rate Parity Theorem (IRPT)}

In connection with the relation between exchange rate and interest rate, there is a theory namely Interest Rate Parity Theorem (IRPT). This theory states that difference percentage between forward exchange rate (Ef) and spot exchange rate (Es) or exchange rate change percentage is determined by interest rate difference in Rupiah in Indonesia (iR) from interest rate in foreign currency (Dollar) in Indonesia or overseas (iV) in international financial market such as New York, London, Tokyo, and Singapore. Forward exchange rate (Ef) is exchange rate for forward transaction, namely spot exchange rate in the future that cannot be known but can only predicted. Whereas spot exchange rate (Es) is exchange rate is for transaction in cash. Whereas exchange rate change percentage can be called depreciation or appreciation, or devaluation or revaluation, depending on the exchange rate system applied.

The formula and theory is [(Ef-Es)/Es] $=(\mathrm{iR}-\mathrm{iV})$, where $(\mathrm{Ef}-\mathrm{Es}) / \mathrm{Es}$ is exchange rate percentage, whereas (iR- iV) is interest rate difference in percentage. This theory can generally be proven with the fact within a short period of less than one year. This is in accordance with interest rate characteristic as the value or price of money that changes in a short period. Various researches by economic experts stated that the difference between theory and fact was mainly caused by transaction cost.

Based on the above theory, risks on exchange rate change from spot (Es) to forward exchange rate (Ef) for each transaction can be overcome by hedging. Hedging is performed by providing fund in Rupiah at present directly to purchase dollar for future payments. This means that covering the risks of exchange rate change needs expenses amounting to the difference of interest rate in Rupiah and Dollar in Indonesia, because Rupiah fund is sacrificed to purchase an amount of Dollar that pays interest in Dollar. This cost certainly occurs or is usually called Forward Premium, because when hedging is performed, spot exchange rate (Es) is know, interest rate in Rupiah (iR) and interest rate in Dollar in Indonesia or overseas (iv). On the other hand, if hedging is not performed but only waiting, the exchange rate that occurs in at the payment time in the future, namely in "open position" method or speculation, so if forward exchange rate is higher than spot exchange rate, profit will be earned (forward premium). But on the other hand, if forward exchange rate is smaller than spot exchange rate, loss will arise (forward discount). Annualized Forward Premium (+) or Forward Discount (-) formula is $[(\mathrm{Ef}-\mathrm{Es}) / \mathrm{Es}] \mathrm{x}[($ transaction period in days $) / 360] \times 100 \%$. 


\section{B. Purchasing Power Parity Theorem (PPPT)}

In general, if purchasing power parity is violated, exposure to exchange rate risk is not limited to firms with direct foreign trade activities. This theory states that exchange rate $(E)$ is ratio between domestic price level of a country $(\mathrm{Pd})$ and price level in trade partner country or price level in several trade partner countries calculated compositely $(\mathrm{P})$, so $\mathrm{E}=\mathrm{Pd} / \mathrm{Pf}$. Whereas viewed from the change, this theory states that the percentage of exchange rate change is inflation difference in a country (IND) and inflation in a trade partner country bilaterally and multilaterally (INF). The exchange rate change is the difference in forward exchange rate (Ef) and spot exchange rate (Es) as stated in IPRT, namely (Ef - Es) / Es. Therefore, formulation of this theory is [(Ef - Es) / Es] x 100\%= (IND) - (INF), where (IND) - (INF) is inflation difference. Concerning this theory, there is a question about which price should be used. Viewed from price level aspect, there are 2 types, namely the Law of One Price (LOOP) and the Absolute Purchasing Power Parity (APPP) based on Levi (1990). Whereas, viewed from exchange rate change and price change, there is one type, the Relative Purchasing Power Parity (RPPP). These three models of PPPT are described as follows.

a. LOOP states that with a certain assumption, there are free trade and homogenous goods or service, and by ignoring transportation cost, $\mathrm{E}$ is ratio of price level of each of homogenous goods or services between 2 countries or between a country and several trade partner countries calculated compositely. So $\mathrm{E}=\mathrm{Pdi} / \mathrm{Pfi}$, where i states each homogenous goods or service.

b. APPP states that if LOOP occurs, $\mathrm{E}$ is ratio of living cost price between 2 countries or between a country and several trade partner countries calculated compositely. Living cost is total consumption expenditure of each household for all goods and services purchases for living needs, namely $\sum$ Pfi in one or several trade partners, where $\mathrm{I}=1,2,3, \ldots, \mathrm{N}$.

c. RPPP states that percentage of exchange rate change namely depreciation or appreciation, devaluation or revaluation, should be in proportion to the difference in the percentage of living cost change in the home country and overseas bilaterally or multilaterally. So [(Ef Es) $/$ Es] x $100 \%=($ IND) $-($ INF). Based on RPPP and by using consumers' price in inflation, so [(Ef - Es) / Es] x 1020\% = (IND) - (INF), where IND and INF constitute inflation based on Consumer Price Index.

\section{Type of Exposures}

Based on Madura (2008), exposure to exchange rate fluctuations comes in three forms:

a. Transaction exposure

The value of a firm's future contractual transactions in foreign currencies is affected by exchange rate movements. The sensitivity of the firm's contractual transactions in foreign currencies to exchange rate movements is referred to as transaction exposure.

b. Economic exposure

The value of a firm's cash flows can be affected by exchange rate movements if it executes transactions in foreign currencies, receives revenue from foreign customers, or is subject to foreign competition.

c. Translation exposure

An MNC creates its financial statements by consolidating all of its individual subsidiaries' financial statements. A subsidiary's financial statement is normally measured in its local currency. To be consolidated, each subsidiary's financial statement must be translated into the currency of the MNC's parent. Since exchange rates change over time, the translation 
of the subsidiary's financial statement into a different currency is affected by exchange rate movements. Translation exposure or exchange-rate exposure refers to the sensitivity of a firm's market value to unanticipated exchange-rate movements (Adler, 1983). The exposure of the MNC's consolidated financial statements to exchange rate fluctuations is known as translation exposure.

\section{Hedging Techniques}

To manage the unexpected exchange-rate movements there are many hedging techniques that can be used for foreign currency risk management. The company can choose a hedging technique that is suitable with the risk encountered by each division. Whereas foreign currency techniques that can be frequently used to apply hedging strategy in foreign currency market are forward, future, options, swaps and money market hedge.

a. Forward

Generally, a forward contract gives its holder both the right and the full obligation to conduct a transaction involving another security or commodity-the underlying asset-at a predetermined future date and at a predetermined price. The future date on which the transaction is to be consummated is called the contract's maturity (or expiration) date, while the predetermined price at which the trade takes place is the forward contract price. Notice there must always be two parties (sometimes called counterparties) to a forward transaction, who delivers the security for the fixed price. One advantage of this private arrangement is that the terms of the contract are completely flexible; they can be whatever any two mutually consenting counterparties agree to.

b. Futures

Futures contracts solve Forward's problem by standardizing the terms of the agreement to the extent that it can be exchange traded. In contrast to the forward market, both parties in a futures contract trade through a centralized market, called a futures exchange. Although the standardization of contracts reduces the ability of the ultimate end users to select the most desirable terms, it does create contract homogeneity, whereby the counterparties can always unwind a previous commitment prior to expiration by simply trading their existing position back to the exchange at the prevailing market price.

c. Options

An option contract gives its holder the right-but not the oblgation-to conduct a transaction involving an underlying security or commodity at a predetermined future date and at a predetermined price. On the other hand, the seller (or writer) of the option must perform on his side of the agreement if the buyer chooses to exercise the option. Thus, the obligation in the option market is inherently one-sided; buyers can do as they please, but sellers are obligated to the buyers under the terms of the agreement. As a consequence, two different types of options are needed to cover all potential transactions: a call optionthe right to buy the underlying security-and a put option-the right to sell that same asset.

d. Swaps

According to Bodie \& Merton (2000), a swap contract consists of two parties exchanging (or "swapping") a series of cash flows at specified intervals over a specified period of time. The swap payments are based on an agreed principal amount (the notional amount). There is no immediate payment of money and, hence, the swap agreement itself provides no new funds to either party. 
The swap contract is, therefore, equivalent to a series of forward contracts. The notional amount in the swap contract corresponds to the face value of the implied forward contracts.

e. Money Market Hedge

Money market hedge is borrowing and lending in multiple currencies, for example to eliminate currency risk by locking in the value of a foreign currency transaction in one's own country's currency. This involves taking a money market position to cover a future payables or receivables position. If a firm has excess cash, it can create a simplified money market hedge (Madura, 2008)

\section{RESEARCH METHODOLOGY}

Just like any other industry, the IPP industry also facing many operational risks. In case of the risk that PDP facing is how to maintain the stability of their cash inflow and outflow which caused by the revenue which is in IDR and the reoccurred expenses such as the gas supply payment to Pertamina and full maintenance expense to Turbomach which both are in USD.

Based on the company operational data since January 2007 to October 2008, Gas Fuel Cost is $57 \%$ of the total revenue and for Machinery and Spare parts Repair and Maintaining Cost is $7 \%$ of the total revenue.

To anticipate the above-mentioned risks, currently PDP is applying open position and does not make hedging. The company only makes speculation against USD currency purchase and it has caused significant loss when there is turmoil to USD/IDR rate.

By knowing the importance of hedging to minimize risk faced by PDP, then PDP has yet to identify some possible alternatives to overcome currency exchange rate exposure.

The possible options are:

A. Hedging by using Forward contract

B. Hedging by using Money Market Hedge

C. Hedging by using Options

Those solutions are chosen by considering currency exchange rate risk, hedging cost and other requirements to apply them as well as real condition faced by the company now.

Based on the three alternatives, the writer applies the three hedging products into company operational transaction to pay gas fuel and full maintenance in the period of 2007 and 2008; so that it seems that the company applies forward contract or money market hedge for the same transaction period. To obtain optimum result for PDP the writer use historical data of 2007 and 2008 from existing forward product and money market hedge.

After rate of profit/loss using forward product and money market hedge, a comparison of profit/loss using real forward product and money market hedge is conducted or by not using hedging (open position) for 2007 and 2008. Moreover the writer is trying to make simulation of the two hedging product for period of 2009.

Based on the comparison of using and not using hedging, the writer will make conclusion from the analyze result which has been conducted to minimize exchange rate risk. Eventually it is the company decision whether or not they use hedging in overcoming exchange rate exposure. 
The analysis model and method applied by the writer in this thesis is strategic problem solving according to The McKinsey Mind (Ethan M. Rasiel and Paul N. Friga, 2001) concerning problem solving process divided into three parts, namely managing, analyzing, and presenting.

In order to attain the target, each company is forced to improve its capacities each year. This lead into more gas supply needed in order to keep up with the requirement demand. As we all know that the price of gas commodity is floating and on the other hand the price of electricity is fixed. To affirm that the strategy adopted by the company is correct and capable to minimize the risks in currency, there are 3 measures taken as a problem solving method, namely:

A. To disclose all of the flow included in the related process (from invoice receive date until the settlement date);

B. To analyze issues and targets determined by the company;

C. To expose issues and draw a solution and calculate risks encountered by the Company those are being implemented.

D. The success of the hedging implementation itself will highly depend on the decision applied by the organization. This problem solving process itself will certainly need accurate data and intuition on the situation to encounter.

The data are collected to know issues and find solutions to the issues. Therefore, we interact with the relevant management and working level of the relevant company in the following manners:

A. Direct interview with source persons (management or working level or expert in relevant sector);

B. Communication via telephone and e-mail;

C. Literature study through journals available at the library and online media;

D. Inspection of the company's financial statement of each semester;

E. Direct data collection from the company's internal application (web);

F. Arrangement of relevant simulations.

Validity and reliability of GFP highly depend on how far the proposals filed can be applied by the management for improvement of aspects that become GFP objects. In this case, how far the proposals given in the hedging application by the management of PDP are applied to improve the management's capability against the existing currency risks, which eventually will improve the future and current cash flow performance of PDP.

\section{RESULT}

\section{Simulation Analysis on The Needs of Hedging}

As described in the previous tables, when applying open position, profit/(loss) of PDP from exchange rate in 2007 was not too large and material because the exchange rate of Rupiah to USD was relatively stable. However in 2008, there was considerable and material profit/(loss) occurred. This encouraged PDP to perform hedging in the future, because the exchange rate of Rupiah to USD was expected to be unstable in the 2009 onwards.

As we previously describe that The PDP contract agreement to Pertamina allows the company to pay the bill in 15 working days after the invoiced received by PDP. So based on 
the agreement above we know that the company is exposed to 15 days currency rate exposure. Other than payment to Pertamina, PDP also have to pay the quarterly maintenance fee to Turbomach denominated in USD. As it is written on the contract agreement between PDP and Turbomach, the maximum grace period is 90 days after the invoiced received. The invoice will be sent to PDP at every first week of January, April, July, and October every year, which the payments are due to 90 days after the received date.

In order to validate whether PDP needs to hedge or not to hedge, first we have to calculate the currency risk and the hedging premium. Currency risk is the percentage of movement between the forward rate at the settlement date and the spot rate at the beginning. The currency can be analysis as below:

Currency risk $=\underline{E f-E s}$

$$
\text { Es }
$$

- $\mathrm{Ef}=$ forward exchange rate at the actual payment time to Pertamina and Turbomach after PDP receives its invoices

- Es $=$ the company's exchange rate or middle exchange rate of Bank Indonesia when PDP receives invoices from Pertamina and Turbomach.

By using the equation above, we can analyze whether the hedging implementation will mitigate the company foreign exchange loss. The PDP payment to both Pertamina and Turbomach between the 2007 and 2008 periods which saw the USD increased greatly in the last quarter of 2008 can be seen in the next table.

Table1. USD/IDR Rate Risk 2007 \& 2008

\begin{tabular}{|c|c|c|c|c|}
\hline $\begin{array}{l}\text { Invoice } \\
\text { Due date }\end{array}$ & $\begin{array}{l}\text { Outstanding } \\
\text { days } \\
\end{array}$ & $\begin{array}{l}\text { FORWARD } \\
\text { RATE (Ef) } \\
\end{array}$ & $\begin{array}{c}\text { SPOT } \\
\text { RATE (Es) } \\
\end{array}$ & $\begin{array}{l}\% \text { Fluctuation } \\
\text { Rate (Ef-Es/Es) }\end{array}$ \\
\hline \multicolumn{5}{|c|}{ PERTAMINA } \\
\hline 31-Jan-2007 & 49 & $9.132,00$ & $9.000,00$ & 1,479 \\
\hline $28-F e b-2007$ & 83 & $9.050,00$ & $9.000,00$ & $0,56 \%$ \\
\hline 2-Apr-2007 & 59 & $8.833,00$ & $9.000,00$ & $-1,869$ \\
\hline 30-Apr-2007 & 51 & $8.935,00$ & $9.000,00$ & $-0,729$ \\
\hline 31-Mei-2007 & 47 & $9.090,00$ & $9.000,00$ & 1,0096 \\
\hline 2-Jul-2007 & 49 & $9.455,00$ & $9.400,00$ & $0,59 \%$ \\
\hline 31-Jul-2007 & 55 & $9.170,00$ & $9.200,00$ & $-0,33 \%$ \\
\hline 31-Agust-2007 & 52 & $9.125,00$ & $9.120,00$ & $0,05 \%$ \\
\hline 1-okt-2007 & 42 & $9.295,00$ & $9.140,00$ & $1,70 \%$ \\
\hline $31-0 k t-2007$ & 37 & $9.285,00$ & $9.140,00$ & $1,59 \%$ \\
\hline 30-Nop-2007 & 39 & $9.544,00$ & $9.350,00$ & $2,07 \%$ \\
\hline 31-Des-2007 & 35 & $9.237,00$ & $9.419,00$ & $-1,93 \%$ \\
\hline 31-Jan-2008 & 41 & $9.170,00$ & $9.000,00$ & 1,899 \\
\hline 29-Feb-2008 & 47 & $9.215,00$ & $9.000,00$ & 2,3996 \\
\hline 31-Mar-2008 & 42 & $9.356,40$ & $9.000,00$ & 3,9696 \\
\hline 30-Apr-2008 & 77 & $9.184,00$ & $9.000,00$ & 2,0496 \\
\hline 2-Jun-2008 & 85 & $9.223,00$ & $9.000,00$ & $2,48 \%$ \\
\hline 30-Jun-2008 & 78 & $9.480,00$ & $9.400,00$ & $0,85 \%$ \\
\hline 31-Jul-2008 & 117 & $12.740,00$ & $9.200,00$ & $38,48 \%$ \\
\hline 1-Sep-2008 & 52 & $10.050,00$ & $9.120,00$ & $10,20 \%$ \\
\hline 30-Sep-2008 & 65 & $11.848,57$ & $9.140,00$ & $29,63 \%$ \\
\hline $31-0 k t-2008$ & 40 & $10.890,86$ & $9.140,00$ & $19,16 \%$ \\
\hline \multicolumn{5}{|c|}{ TURBOMACH } \\
\hline 1-Mar-2007 & 90 & $8.554,58$ & $9.000,00$ & $-4,9596$ \\
\hline 6 -Jun-2007 & 128 & $8.931,41$ & $9.120,00$ & $-2,07 \%$ \\
\hline 21-Jan-2008 & 22 & $9.221,00$ & $9.350,00$ & $-1,38 \%$ \\
\hline 21-Jan-2008 & 80 & $8.915,80$ & $9.291,00$ & $-4,049$ \\
\hline \multicolumn{3}{|c|}{ Total } & $=$ & $102,83 \pi$ \\
\hline & \multicolumn{3}{|c|}{ AVERAGE RATE FLUCTUATION(RATE RISK) } & $3,95 \%$ \\
\hline
\end{tabular}


After that, the Company still have to count the hedging premium, especially if they want to use the money market fund, which also an alternative to mitigate the currency risk. Please refer to below formula:

Hedging Premium $=$ ip - is

- $\quad$ ip $=$ IDR loan interest rate (p.a) $\times$ loan periods $/ 360$ days

- $\quad$ is $=$ USD deposit interest rate (p.a) $\mathrm{x}$ deposit period $/ 360$ days

By using the equation above, we can analyze whether this hedging implementation will mitigate the company foreign exchange loss. The PDP payment to both Pertamina and Turbomach between the 2007 and 2008 periods which saw the USD increased greatly in the last quarter of 2008 can be seen in the next table.

Table 2. Hedging Cost 2007 \& 2008

\begin{tabular}{|c|c|c|c|c|c|c|c|c|}
\hline $\begin{array}{l}\text { INVOICE DATE } \\
\text { PERTAMINA } \\
\end{array}$ & $\begin{array}{l}\text { INVOICE } \\
\text { SETTLED }\end{array}$ & LOAN TERM (DAYS) & $\begin{array}{l}\text { LOAN RATE i\% } \\
\text { (IDR) }\end{array}$ & $\begin{array}{l}\text { INTEREST } \\
\text { PAID } \\
\text { (ip) } \\
\end{array}$ & $\begin{array}{l}\text { DEPOSIT RATE I\% } \\
\text { (USD) }\end{array}$ & $\begin{array}{l}\text { DEPOSIT TERM } \\
\text { (DAYS) }\end{array}$ & $\begin{array}{l}\text { INTEREST } \\
\text { EARN } \\
\text { is } \\
\end{array}$ & $\begin{array}{c}\text { SPREAD BETWEEN INTEREST } \\
\text { PAID \& INTEREST EARN } \\
\% \text { (ip-is) }\end{array}$ \\
\hline 31-Jan-07 & 21-Mar-07 & 49 & $15.89 \%$ & $2.16 \%$ & $5.25 \%$ & 49 & $0.71 \%$ & $1.45 \%$ \\
\hline 28-Feb-07 & 22-May-07 & 83 & $13.50 \%$ & $3.11 \%$ & $5.25 \%$ & 83 & $1.21 \%$ & $1.90 \%$ \\
\hline 2-Apr-07 & 31-May-07 & 59 & $13.50 \%$ & $2.21 \%$ & $5.25 \%$ & 59 & $0.86 \%$ & $1.35 \%$ \\
\hline 30-Apr-07 & 20-Jun-07 & 51 & $13.50 \%$ & $1.91 \%$ & $5.25 \%$ & 51 & $0.74 \%$ & $1.17 \%$ \\
\hline 31-May-07 & 17-Jul-07 & 47 & $12.92 \%$ & $1.69 \%$ & $5.25 \%$ & 47 & $0.69 \%$ & $1.00 \%$ \\
\hline 2-Jul-07 & 20-Aug-07 & 49 & $12.92 \%$ & $1.76 \%$ & $5.25 \%$ & 49 & $0.71 \%$ & $1.04 \%$ \\
\hline 31-Jul-07 & 24-Sep-07 & 55 & $12.92 \%$ & $1.97 \%$ & $5.25 \%$ & 55 & $0.80 \%$ & $1.17 \%$ \\
\hline 31-Aug-07 & $22-0 c t-07$ & 52 & $12.50 \%$ & $1.81 \%$ & $5.25 \%$ & 52 & $0.76 \%$ & $1.05 \%$ \\
\hline $1-0 c t-07$ & 12-Nov-07 & 42 & $12.50 \%$ & $1.46 \%$ & $5.00 \%$ & 42 & $0.58 \%$ & $0.88 \%$ \\
\hline 31-0ct-07 & 7-Dec-07 & 37 & $12.50 \%$ & $1.28 \%$ & $5.00 \%$ & 37 & $0.51 \%$ & $0.77 \%$ \\
\hline 30-Nov-07 & 8-Jan-08 & 39 & $12.50 \%$ & $1.35 \%$ & $4.75 \%$ & 39 & $0.51 \%$ & $0.84 \%$ \\
\hline 31-Dec-07 & 4-Feb-08 & 35 & $12.50 \%$ & $1.22 \%$ & $4.75 \%$ & 35 & $0.46 \%$ & $0.75 \%$ \\
\hline 31-Jan-08 & 12-Mar-08 & 41 & $12.50 \%$ & $1.42 \%$ & $4.00 \%$ & 41 & $0.46 \%$ & $0.97 \%$ \\
\hline $29-F e b-08$ & 16-Apr-08 & 47 & $11.67 \%$ & $1.52 \%$ & $3.50 \%$ & 47 & $0.46 \%$ & $1.07 \%$ \\
\hline 31-Mar-08 & 12-May-08 & 42 & $11.67 \%$ & $1.36 \%$ & $2.75 \%$ & 42 & $0.32 \%$ & $1.04 \%$ \\
\hline 30-Apr-08 & 16-Jul-08 & 77 & $11.67 \%$ & $2.50 \%$ & $2.50 \%$ & 77 & $0.53 \%$ & $1.96 \%$ \\
\hline 2-Jun-08 & 26-Aug-08 & 85 & $11.00 \%$ & $2.60 \%$ & $2.00 \%$ & 85 & $0.47 \%$ & $2.13 \%$ \\
\hline 30-Jun-08 & 16-Sep-08 & 78 & $11.00 \%$ & $2.38 \%$ & $2.00 \%$ & 78 & $0.43 \%$ & $1.95 \%$ \\
\hline 31-Jul-08 & 25-Nov-08 & 117 & $11.00 \%$ & $3.58 \%$ & $2.00 \%$ & 117 & $0.65 \%$ & $2.93 \%$ \\
\hline 1-Sep-08 & 23-0ct-08 & 52 & $11.50 \%$ & $1.66 \%$ & $2.00 \%$ & 52 & $0.29 \%$ & $1.37 \%$ \\
\hline 30-Sep-08 & 4-Dec-08 & 65 & $11.50 \%$ & $2.08 \%$ & $2.00 \%$ & 65 & $0.36 \%$ & $1.72 \%$ \\
\hline 31-0ct-08 & 10-Dec-08 & 40 & $11.50 \%$ & $1.28 \%$ & $2.50 \%$ & 40 & $0.28 \%$ & $1.00 \%$ \\
\hline 1-Dec-08 & 31-Dec-08 & 30 & $11.50 \%$ & $0.96 \%$ & $0.70 \%$ & 30 & $0.06 \%$ & $0.90 \%$ \\
\hline 31-Dec-08 & 31-Jan-09 & 31 & $11.50 \%$ & $0.99 \%$ & $0.70 \%$ & 31 & $0.06 \%$ & $0.93 \%$ \\
\hline \multicolumn{9}{|l|}{ TURBOMACH } \\
\hline 14-Dec-06 & 23-Jan-07 & 40 & $15.89 \%$ & $1.77 \%$ & $5.25 \%$ & 40 & $0.58 \%$ & $1.18 \%$ \\
\hline 1-Mar-07 & 30-May-07 & 90 & $13.50 \%$ & $3.38 \%$ & $5.25 \%$ & 90 & $1.31 \%$ & $2.06 \%$ \\
\hline 6-Jun-07 & 12-0ct-07 & 128 & $12.50 \%$ & $4.44 \%$ & $5.25 \%$ & 128 & $1.87 \%$ & $2.58 \%$ \\
\hline 21-Jan-08 & 12-Feb-08 & 22 & $12.50 \%$ & $0.76 \%$ & $4.00 \%$ & 22 & $0.24 \%$ & $0.52 \%$ \\
\hline 21-Jan-08 & 10-Apr-08 & 80 & $12.50 \%$ & $2.78 \%$ & $4.00 \%$ & 80 & $0.89 \%$ & $1.89 \%$ \\
\hline 25-Mar-08 & 23-Jun-08 & 90 & $11.67 \%$ & $2.92 \%$ & $2.75 \%$ & 90 & $0.69 \%$ & $2.23 \%$ \\
\hline 25-Jun-08 & 16-0ct-08 & 113 & $11.00 \%$ & $3.45 \%$ & $2.00 \%$ & 113 & $0.63 \%$ & $2.83 \%$ \\
\hline 6-0ct-08 & 31-Dec-08 & 86 & $11.50 \%$ & $2.75 \%$ & $2.50 \%$ & 86 & $0.60 \%$ & $2.15 \%$ \\
\hline \multicolumn{9}{|c|}{ TOTAL $\quad 36.55 \%$} \\
\hline & & & Hedging Cost: & anges & a detwee il inte & parco ainu inte & tearn $=$ & $1.41 \%$ \\
\hline
\end{tabular}


Table 3. Comparison Gain/(Loss) using Forward and Open Position

\begin{tabular}{|c|c|c|c|c|c|c|}
\hline \multicolumn{7}{|c|}{ PERTAMINA } \\
\hline $\begin{array}{l}\text { PERIOD } \\
2007 \\
\end{array}$ & $\begin{array}{c}\text { GAS } \\
\text { EXPENSE(USD) } \\
\end{array}$ & $\begin{array}{l}\text { COMPANY } \\
\text { RATE }\end{array}$ & $\begin{array}{l}\text { FORWARD } \\
\text { RATE }\end{array}$ & $\begin{array}{l}\text { GAIN/(LOSS)FOREX FROM } \\
\text { OPEN POSITION(IDR) }\end{array}$ & $\begin{array}{l}\text { GAIN/(LOSS)FOREX FROM } \\
\text { FORWARD(IDR) }\end{array}$ & GAIN FROM USING FORWARD \\
\hline January & $318.784,56$ & $9.000,00$ & $9.211,00$ & $(42.079 .562)$ & $(67.263 .542,16)$ & $(25.183 .980,24)$ \\
\hline February & $268.302,08$ & $9.000,00$ & $9.316,00$ & $(13.415 .104,00)$ & $(84.783 .457,28)$ & $(71,368.353,28)$ \\
\hline March & $297.514,17$ & $9.000,00$ & $9.254,00$ & $49.684 .866,39$ & $(75.568 .599,18)$ & $(125.253 .465,57)$ \\
\hline April & $274.372,62$ & $9.000,00$ & $9.198,00$ & $17.834 .220,30$ & $(54.325 .778,76)$ & $(72.159 .999,06)$ \\
\hline May & $286.617,07$ & $9.000,00$ & $8.922,00$ & $(25.795 .536,30)$ & $22.356 .131,46$ & $48.151 .667,76$ \\
\hline June & $267.744,10$ & $9.400,00$ & $9.115,00$ & $(14.725 .925,50)$ & $76.307 .068,50$ & $91.032 .994,00$ \\
\hline July & $275.246,21$ & $9.200,00$ & $9.339,00$ & $8.257 .386,30$ & $(38.259 .223,19)$ & $(46.516 .609,49)$ \\
\hline August & $272.104,94$ & $9.120,00$ & $9.493,00$ & $(1.360 .524,70)$ & $(101.495 .142,62)$ & $(100.134 .617,92)$ \\
\hline September & $264.497,67$ & $9.140,00$ & $9.168,00$ & $(40,997.138,85)$ & $(7.405 .934,76)$ & $33.591 .204,09$ \\
\hline October & $267.503,34$ & $9.140,00$ & $9.166,50$ & $(38.787 .984,30)$ & $(7.088 .838,51)$ & $31.699 .145,79$ \\
\hline November & $263.434,53$ & $9.350,00$ & $9.448,50$ & $(51.106 .394,26)$ & $(25.948 .301,20)$ & $25.158 .093,05$ \\
\hline \multirow[t]{2}{*}{ December } & $267.735,62$ & $9.419,00$ & $9.465,50$ & $48.727 .883,74$ & $(12.449,706,33)$ & $(61.177 .590,07)$ \\
\hline & & & TOTAL & $(103.763 .813,10)$ & $(375.925 .324,04)$ & $(272 \cdot 161.510,94)$ \\
\hline \multicolumn{7}{|l|}{2008} \\
\hline January & $272.425,55$ & $9.291,00$ & $9.328,60$ & $32.963 .492,25$ & $(10.243 .200,48)$ & $(43.206 .692,73)$ \\
\hline February & $264.000,58$ & $9.078,00$ & $9.155,75$ & $(36.168 .075,66)$ & $(20.526 .045,10)$ & $15.642 .030,57$ \\
\hline March & $265.000,58$ & $9.217,00$ & $9.289,00$ & $(36.941 .080,85)$ & $(19.080 .041,76)$ & $17.861 .039,09$ \\
\hline April & $262.832,97$ & $9.234,00$ & $9.382,00$ & $13.141 .648,50$ & $(38.899 .279,56)$ & $(52.040 .928,06)$ \\
\hline May & $305.088,36$ & $9.318,00$ & $9.505,00$ & $28.983 .394,20$ & $(57.051 .523,32)$ & $(86.034 .917,52)$ \\
\hline June & $310.016,54$ & $9.225,00$ & $9.405,50$ & $(79.054,217,70)$ & $(55.957,985,47)$ & $23.096 .232,23$ \\
\hline July & $283.066,75$ & $9.118,00$ & $9.381,50$ & $(1.025 .267 .768,50)$ & $(74.588 .088,63)$ & $950.679 .679,88$ \\
\hline August & $242.954,04$ & $9.160,00$ & $9.287,00$ & $(216.229 .095,60)$ & $(30.855 .163,08)$ & $185.373 .932,52$ \\
\hline September & $234.994,08$ & $9.378,00$ & $9.618,00$ & $(580.568 .224,96)$ & $(56.398 .579,20)$ & $524.169 .645,76$ \\
\hline October & $252.383,45$ & $10.600,00$ & $10.952,00$ & $(73.409 .000,50)$ & $(88.838 .974,40)$ & $(15.429 .973,90)$ \\
\hline November & $251.433,98$ & $12.151,00$ & & - & - & - \\
\hline \multirow[t]{2}{*}{ December } & $255.983,34$ & $10.950,00$ & & - & - & - \\
\hline & & & TOTAL & $(1.972 .548 .928,82)$ & $(452.438 .880,99)$ & $1.520 .110 .047,83$ \\
\hline \multicolumn{7}{|c|}{ TURBOMACH } \\
\hline PERIOD & \begin{tabular}{|l|} 
MAINTENANCE \\
EXPENSE (USD)
\end{tabular} & COMPANY RATE & FORWARD RATE & $\begin{array}{l}\text { GAIN/(LOSS)FOREX FROM } \\
\text { OPEN POSITION(IDR) }\end{array}$ & $\begin{array}{l}\text { GAIN/(LOSS)FOREX FROM } \\
\text { FORWARD(IDR) }\end{array}$ & GAIN FROM USING FORWARD \\
\hline \multicolumn{7}{|c|}{2007} \\
\hline Jan-Mar & $99.375,00$ & $9.000,00$ & - & - & - & - \\
\hline Apr-Jun & $99.375,00$ & $9.000,00$ & $9.355,00$ & $44.264 .053,33$ & $(35.278 .125,00)$ & $(79.542 .178,33)$ \\
\hline Jul-Sept & $99.375,00$ & $9.120,00$ & $9.164,50$ & $18.740 .706,40$ & $(4.422 .187,50)$ & $(23.162 .893,90)$ \\
\hline \multirow[t]{2}{*}{ Oct-Dec } & $99.375,00$ & $9.350,00$ & $9.503,00$ & $12.819 .374,10$ & $(15.204,375,00)$ & $(28.023 .749,10)$ \\
\hline & & & TOTAL & $75.824 .133,83$ & $(54.904 .687,50)$ & $(130.728 .821,33)$ \\
\hline \multicolumn{7}{|c|}{2008} \\
\hline Jan-Mar & $99.375,00$ & $9.291,00$ & $9.627,00$ & $37.285 .802,45$ & $(33.389 .999,93)$ & $(70.675 .802,38)$ \\
\hline Apr-Jun & $99.375,00$ & $9.217,00$ & . & - & - & \\
\hline Jul-Sept & $106.294,35$ & $9.225,00$ & - & - & - & - \\
\hline \multirow[t]{3}{*}{ Oct-Dec } & - & - & - & - & - & \\
\hline & & & TOTAL & $37.285 .802,45$ & $(33.389 .999,93)$ & $(70.675 .802,38)$ \\
\hline & & & & $(1.935 .263 .126,37)$ & & \\
\hline \multicolumn{6}{|c|}{ TOTAL GAIN FROM USING FORWARD: PERTAMINA \& TURBOMACH 2007 \& 2008} & $1.046 .543 .913,19$ \\
\hline \multicolumn{6}{|c|}{ AVERAGE GAIN FROM USING FORWARD FOR 26 PAYMENTS IN 2007 \& 2008} & $40.251 .688,97$ \\
\hline
\end{tabular}

From the table above, PDP can mitigate the risk of loss due to forex amounted by IDR 1 billion or average IDR 40 Million for every payment transaction which occurred in those periods by using forward contract for all the payment periods.

We can see the comparison gain/(loss) using money market hedge and open position for the year ended 2007 and 2008 which generate significant forex gain. 
Table 4. Comparison Gain/(Loss) using Money Market Hedge and Open Position

\begin{tabular}{|c|c|c|c|c|}
\hline & & & & IDR) \\
\hline INVOICE RECEIVED & INVOICE SETTLED & $\begin{array}{l}\text { NET PAID BY } \\
\text { USING MONEY } \\
\text { MARKET HEDGE }\end{array}$ & $\begin{array}{l}\text { NET PAID BY } \\
\text { USING OPEN } \\
\text { POSITION }\end{array}$ & $\begin{array}{l}\text { DIFFERENCE IN } \\
\text { NET PAID }\end{array}$ \\
\hline \multicolumn{5}{|c|}{ PERTAMINA } \\
\hline 31-Jan-07 & 21-Mar-07 & 2.954 .277 .425 & 2.911 .140 .602 & -43.136 .823 \\
\hline 28-Feb-07 & 22-Mei-07 & 2.517 .476 .818 & 2.428 .133 .824 & -89.342 .994 \\
\hline 2-Apr-07 & 31-Mei-07 & 2.761 .697 .863 & 2.627 .942 .664 & -133.755 .200 \\
\hline 30-Apr-07 & 20-Jun-07 & 2.534 .138 .152 & 2.451 .519 .360 & -82.618 .792 \\
\hline 31-Mei-07 & 17-Jul-07 & 2.567 .901 .657 & 2.605 .349 .166 & 37.447 .509 \\
\hline 2-Jul-07 & 20-Agust-07 & 2.451 .419 .897 & 2.531 .520 .466 & 80.100 .568 \\
\hline 31-Jul-07 & 24-Sep-07 & 2.570 .986 .323 & 2.524 .007 .746 & -46.978 .577 \\
\hline 31-Agust-07 & 22-okt-07 & 2.600 .929 .619 & 2.482 .957 .578 & -117.972 .042 \\
\hline 1-okt-07 & 12-Nop-07 & 2.440 .301 .239 & 2.458 .505 .843 & 18.204 .603 \\
\hline 31-okt-07 & 7-Des-07 & 2.466 .066 .385 & 2.483 .768 .512 & 17.702 .126 \\
\hline 30-Nop-07 & 8-Jan-08 & 2.503 .020 .892 & 2.514 .219 .250 & 11.198 .358 \\
\hline 31-Des-07 & 4-Feb-08 & 2.481 .410 .252 & 2.473 .073 .921 & -8.336 .331 \\
\hline 31-Jan-08 & 12-Mar-08 & 2.568 .468 .438 & 2.498 .142 .294 & -70.326 .145 \\
\hline 29-Feb-08 & 16-Apr-08 & 2.426 .819 .447 & 2.432 .765 .345 & 5.945 .898 \\
\hline 31-Mar-08 & 12-Mei-08 & 2.480 .166 .211 & 2.479 .451 .427 & -714.785 \\
\hline 30-Apr-08 & 16-Jul-08 & 2.487 .064 .244 & 2.413 .857 .996 & -73.206 .248 \\
\hline 2-Jun-08 & 26-Agust-08 & 2.915 .567 .463 & 2.813 .829 .944 & -101.737 .519 \\
\hline 30-Jun-08 & 16-Sep-08 & 2.929 .928 .756 & 2.938 .956 .799 & 9.028 .043 \\
\hline 31-Jul-08 & 25-Nop-08 & 2.663 .319 .287 & 3.606 .270 .395 & 942.951 .108 \\
\hline 1-Sep-08 & 23-0kt-08 & 2.267 .475 .087 & 2.441 .688 .102 & 174.213 .015 \\
\hline 30-Sep-08 & 4-Des-08 & 2.239 .478 .840 & 2.784 .342 .707 & 544.863 .867 \\
\hline 31-okt-08 & 10-Des-08 & 2.816 .837 .059 & 2.748 .673 .571 & -68.163 .489 \\
\hline TOTAL & & 56.644 .751 .355 & 57.650 .117 .509 & 1.005 .366 .154 \\
\hline \multicolumn{5}{|c|}{ TURBOMACH } \\
\hline 1-Mar-07 & 30-Mei-07 & 931.482 .738 & 850.110 .947 & -81.371 .791 \\
\hline 6-Jun-07 & 12-okt-07 & 907.178 .060 & 887.559 .294 & -19.618 .766 \\
\hline 21-Jan-08 & 12-Feb-08 & 949.034 .154 & 916.336 .876 & -32.697 .278 \\
\hline 21-Jan-08 & 10-Apr-08 & 962.410 .838 & 886.007 .323 & -76.403 .515 \\
\hline TOTAL & & 3.750 .105 .789 & 3.540 .014 .439 & $(210.091 .350)$ \\
\hline \multicolumn{5}{|c|}{ TOTAL NET PAID SAVING BY USING MONEY MARKET HEDGE = } \\
\hline
\end{tabular}

We can see from the table above that PDP can save IDR 795 million by using money market hedge instead open position.

\section{Hedging Strategy for 2009 Onwards}

Based on our simulation analysis on the 2007 and 2008 historical data, we conclude that by using hedge on either forward contract or money market fund, the Company can avoid the risk of currency exposure in most occasions. However, in order to perform hedging, whether with Money Market Hedge or derivatives products, professionals are required, which are not easy to find and implement. The company often has to incur extra money and efforts to implement it. That's why as it is agreed before, that we will try to make a sensitivity analysis 
simulation on their 2009 payment schedule. Based on the objectivity that we are trying to give the Company the best solution for this matter, we obtain some of the most commonly use hedging products/methods later on.

\section{Hedging Product Offered}

In order to be able to give the most suitable solution for the Company, we choose a variety of hedging products and money market funds whether actual or simulated from their historical transactions. We suggest some of these products from these trusted banks which are commonly used in the market as below:

Table 4. Product Offered

\begin{tabular}{|c|c|c|c|c|c|c|c|c|c|c|}
\hline \multirow{2}{*}{$\begin{array}{l}\text { Invoice } \\
\text { Due date }\end{array}$} & \multirow{3}{*}{\begin{tabular}{|l|} 
Payment \\
Due date \\
\end{tabular}} & \multicolumn{9}{|c|}{ Products } \\
\hline & & \multicolumn{3}{|c|}{ BANK PERMATA (simulated) } & \multicolumn{2}{|c|}{ BANK MANDIRI } & \multicolumn{2}{|c|}{ BANK BCA } & \multicolumn{2}{|c|}{ RBS (simulated) } \\
\hline PERTAMINA & & $\begin{array}{c}\text { Forward } \\
\text { Price } \\
\end{array}$ & $\begin{array}{c}\text { Option } \\
\text { Exercise } \\
\text { Price } \\
\end{array}$ & $\begin{array}{c}\text { Option } \\
\text { Premium } \\
\end{array}$ & $\begin{array}{l}\text { Loan } \\
\text { Rate } \\
\end{array}$ & $\begin{array}{c}\text { Deposit } \\
\text { Rate } \\
\end{array}$ & $\begin{array}{l}\text { Loan } \\
\text { Rate } \\
\end{array}$ & $\begin{array}{c}\text { Deposit } \\
\text { Rate } \\
\end{array}$ & $\begin{array}{l}\text { Loan } \\
\text { Rate } \\
\end{array}$ & $\begin{array}{c}\text { Forward } \\
\text { Price } \\
\end{array}$ \\
\hline $1 / 30 / 09$ & $4 / 12 / 66$ & 11,426 & 11,426 & 343 & $11.0 \%$ & $2.8 \%$ & $13.0 \%$ & $3.0 \%$ & $1.0 \%$ & 11,436 \\
\hline $27 / 09$ & $6 / 09$ & 12,028 & 12,028 & 361 & $11.0 \%$ & $2.8 \%$ & $13.0 \%$ & $3.0 \%$ & $1.0 \%$ & 12,038 \\
\hline $31 / 09$ & $4 / 15 / 09$ & 12,000 & 12,000 & 360 & $11.0 \%$ & $2.8 \%$ & $13.0 \%$ & $3.0 \%$ & $1.0 \%$ & 12,010 \\
\hline 30/09 & $5 / 15 / 09$ & 11,975 & 11,975 & 359 & $11.0 \%$ & $2.8 \%$ & $13.0 \%$ & $3.0 \%$ & $1.0 \%$ & 11,985 \\
\hline $1 / 09$ & $6 / 16 / 09$ & 11,901 & 11,901 & 357 & $11.0 \%$ & $2.8 \%$ & $13.0 \%$ & $3.0 \%$ & $1.0 \%$ & 11,911 \\
\hline 3009 & 7/15/09 & 11,798 & 11,798 & 354 & $11.0 \%$ & $2.8 \%$ & $13.0 \%$ & $3.0 \%$ & $1.0 \%$ & 11,808 \\
\hline $31 / 09$ & $8 / 17 / 09$ & 11,687 & 11,687 & 351 & $11.0 \%$ & $2.8 \%$ & $13.0 \%$ & $3.0 \%$ & $1.0 \%$ & 11,697 \\
\hline $1 / 09$ & $9 / 15 / 09$ & 11,574 & 11,574 & 347 & $11.0 \%$ & $2.8 \%$ & $13.0 \%$ & $3.0 \%$ & $1.0 \%$ & 11,584 \\
\hline 0,09 & 10/15/09 & 11,464 & 464 & 344 & $11.0 \%$ & $2.8 \%$ & $13.0 \%$ & $3.0 \%$ & $1.0 \%$ & .474 \\
\hline $2 / 09$ & $11 / 17 / 09$ & 11,342 & 342 & 340 & $11.0 \%$ & $2.8 \%$ & $13.0 \%$ & $3.0 \%$ & $1.0 \%$ & 11,352 \\
\hline $130 / 09$ & $12 / 15 / 09$ & 11,338 & 338 & 340 & $11.0 \%$ & $2.8 \%$ & $13.0 \%$ & $3.0 \%$ & $1.0 \%$ & 11,348 \\
\hline $12 / 31 / 09$ & $1 / 15 / 10$ & 11,430 & 11,430 & 343 & $11.0 \%$ & $2.8 \%$ & $13.0 \%$ & $3.0 \%$ & $1.0 \%$ & 11,440 \\
\hline \multicolumn{11}{|l|}{ TURBOMACH } \\
\hline $12 / 31 / 08$ & $3 / 31 / 09$ & 11,505 & 11,505 & 575 & $11.0 \%$ & $2.8 \%$ & $13.0 \%$ & $3.0 \%$ & $1.0 \%$ & 11,490 \\
\hline $13 / 09$ & 6/11/09 & 12,480 & 12,480 & 624 & $11.0 \%$ & $2.8 \%$ & $13.0 \%$ & $3.0 \%$ & $1.0 \%$ & 12,465 \\
\hline $6 / 15 / 09$ & $9 / 14 / 09$ & 12,315 & 12,315 & 616 & $11.0 \%$ & $2.8 \%$ & $13.0 \%$ & $3.0 \%$ & $1.0 \%$ & 12,300 \\
\hline 10/9/09 & $1 / 7 / 10$ & 11,894 & 11,894 & 595 & $11.0 \%$ & $2.8 \%$ & $13.0 \%$ & $3.0 \%$ & $1.0 \%$ & 11,879 \\
\hline
\end{tabular}

\section{Forecasting Rate}

Exercise In making simulation of hedging products available in the market, firstly we need to determine or identify spot rate changes from IDR to USD along the year particularly when invoice dates are accepted and the invoice dates are paid.

Based on our scope as contained in the previous chapter where only limited to analyzing which the best hedging technique to mitigate transaction and economic exposure faced by PDP, we will only make forecast spot rate based forecast data within the year from Bloomberg online. The data we use is average data of USD/IDR projection based on the survey conducted by Bloomberg distributed by several reputable banks all over the world which then put into statistics into Mean, Median and Low so then it will present data as displayed in the following illustration

The data are data per quarterly, in which they are the most accurate data we could collect. However to be able to forecast actual spot rate every invoice period that is due and invoice paid, we use simple sample in which rate of every quarter we determine in the middle of the quarter itself, that is, Quarter 1 (January-March) fall on 15th February, Quarter 2 (AprilMay) fall on 15th May, Quarter 3 fall on 15 August and Quarter 4 fall on 15th November. 
Based on our above basic assumption, we will try to draw simple moving average rate for every date of our payment invoice so that we can get spot rate on every invoice date, along with the median, lowest and highest point. To record the data when an invoice is accepted, we use rate of Mean, then for Sensitivity Analysis we use Median, Low and High rate for each scenario, which is described in detail in the next sub-chapter. Meanwhile, spot rate projection data for 2009 is as follows:

Table 5. Forecasting Rate 2009

\begin{tabular}{|l||l|}
\hline $\begin{array}{l}\text { Invoice } \\
\text { Received date }\end{array}$ & MEAN \\
\hline PERTAMINA & \\
\hline 30-Jan-2009 & $11,335.00$ \\
\hline 27-Feb-2009 & $11,936.75$ \\
\hline 31-Mar-2009 & $11,909.43$ \\
\hline 30-Apr-2009 & $11,888.81$ \\
1-Jun-2009 & $11,810.21$ \\
30-Jun-2009 & $11,706.50$ \\
31-Jul-2009 & $11,595.64$ \\
\hline 31-Aug-2009 & $11,483.04$ \\
\hline 30-Sep-2009 & $11,372.50$ \\
\hline 2-Nov-2009 & $11,250.90$ \\
30-Nov-2009 & $11,247.29$ \\
\hline 31-Dec-2009 & $11,338.81$ \\
\hline TURBOMACH & \\
\hline 31-Dec-2008 & $10,950.00$ \\
\hline 13-Mar-2009 & $11,924.80$ \\
\hline 15-Jun-2009 & $11,760.14$ \\
\hline 9-Oct-2009 & $11,339.34$ \\
\hline
\end{tabular}

\begin{tabular}{|c|c|c|c|}
\hline $\begin{array}{l}\text { Invoiced } \\
\text { Settlement date }\end{array}$ & LOW & MEDIAN & HIGH \\
\hline 16-Feb-09 & $9,865.48$ & $11,812.00$ & $13,028.40$ \\
\hline 16-Mar-09 & $10,000.00$ & $11,946.52$ & $13,162.92$ \\
\hline 15-Apr-09 & $10,000.00$ & $11,923.26$ & $13,331.46$ \\
\hline 15-May-09 & $10,000.00$ & $11,900.00$ & $13,500.00$ \\
\hline 16-Jun-09 & $9,904.35$ & $11,760.87$ & $13,500.00$ \\
\hline 15-Jul-09 & $9,817.66$ & $11,634.78$ & $13,500.00$ \\
\hline 17-Aug-09 & $9,719.02$ & $11,491.30$ & $13,500.00$ \\
\hline 15-Sep-09 & $9,634.02$ & $11,331.52$ & $13,500.00$ \\
\hline 15-Oct-09 & $9,545.98$ & $11,168.48$ & $13,500.00$ \\
\hline 17-Nov-09 & $9,449.13$ & $10,989.13$ & $13,500.00$ \\
\hline 15-Dec-09 & $9,505.00$ & $11,109.89$ & $13,554.95$ \\
\hline 15-Jan-10 & $9,556.67$ & $11,223.44$ & $13,611.72$ \\
\hline 31-Mar-09 & $10,000.00$ & $11,934.89$ & $13,247.19$ \\
\hline 11-Jun-09 & $9,919.29$ & $11,782.61$ & $13,500.00$ \\
\hline 14-Sep-09 & $9,636.96$ & $11,336.96$ & $13,500.00$ \\
\hline 7 -Jan-10 & $9,543.33$ & $11,194.14$ & $11,194.14$ \\
\hline
\end{tabular}

\section{Sensitivity Analysis}

In making this sensitivity analysis, we make 3 scenarios for 2009 payment namely Worst Case, Base Case and Best Case in which Worst Case is a scenario which occurs if IDR exchange rate to USD is weakened sharply, Base Case is a scenario when IDR weakened not quite sharply and Best Case is a scenario where IDR exchange rate to USD is strengthened sharply.

The three scenarios use reference from Bloomberg spot rate forecast, in which we will use the median as Base Case spot rate, the highest point as Worst Case and lowest point as Best Case Spot Rate.

After knowing range of every category, we will use individual data of each major bank providing contribution to Bloomberg then forecast them into categories of High, Medium and Low range. Then we will calculate percentage of the all banks divided by the number of the banks. This classification is intended to make conclusion of what is the right probability for each scenario in every quarter.

Table 6. High, Medium, Low per Quarter

\begin{tabular}{|l|r|r|r|r|r|r|r|r|}
\hline \multicolumn{10}{|l|}{ 1st Quarter } \\
Scenario & \multicolumn{2}{|c|}{ 2nd Quarter } \\
\hline High & 13,000 & & 13,500 & & 13,500 & & 13,500 & \\
\hline Spread & 1,031 & 12,485 & 1,629 & 12,686 & 2,000 & $\mathbf{1 2 , 5 0 0}$ & 2,500 & $\mathbf{1 2 , 2 5 0}$ \\
\hline Medium & $\mathbf{1 1 , 9 6 9}$ & & $\mathbf{1 1 , 8 7 1}$ & & $\mathbf{1 1 , 5 0 0}$ & & $\mathbf{1 1 , 0 0 0}$ & \\
\hline Spread & 1,969 & $\mathbf{1 0 , 9 8 5}$ & 1,871 & $\mathbf{1 0 , 9 3 6}$ & 1,775 & $\mathbf{1 0 , 6 1 3}$ & 1,545 & $\mathbf{1 0 , 2 2 8}$ \\
\hline Low & $\mathbf{1 0 , 0 0 0}$ & & $\mathbf{1 0 , 0 0 0}$ & & $\mathbf{9 , 7 2 5}$ & & $\mathbf{9 , 4 5 5}$ & \\
\hline
\end{tabular}


Table 7. Spot Rate Range per Quarter 2009

\begin{tabular}{|c|c|c|c|c|}
\hline Scenario & 1st Quarter & 2nd Quarter & 3rd Quarter & 4th Quarter \\
\hline High & 13,000 to 12,485 & 13,500 to 12,686 & 13,500 to 12,500 & 13,500 to 12,250 \\
\hline Medium & 12,485 to 10,985 & 12,686 to 10,936 & 12,500 to 10,613 & 12,250 to 10,228 \\
\hline Low & 10,985 to 10,000 & 10,936 to 10,000 & 10,613 to 9,725 & 10,228 to 9,455 \\
\hline
\end{tabular}

After knowing range of every category, we will probably use individual data of each major bank providing contribution to Bloomberg then forecast them into categories of High, Medium and Low range. Then we will calculate percentage of the all banks divided by the number of the banks. This classification is intended to make conclusion of what is the right probability for each scenario in every quarter. Below are spot rate data of each contributor banks

Then in determining value of every scenario, we will make range spot rate for each scenario in order to be able to be used in valuing Worst Case, Base Case, Best Case probability by drawing the central point of High, Low and Median in order to be able to make range of every scenario as seen in the following table:

Table 8. Scenario Probability From Top 10 Banks

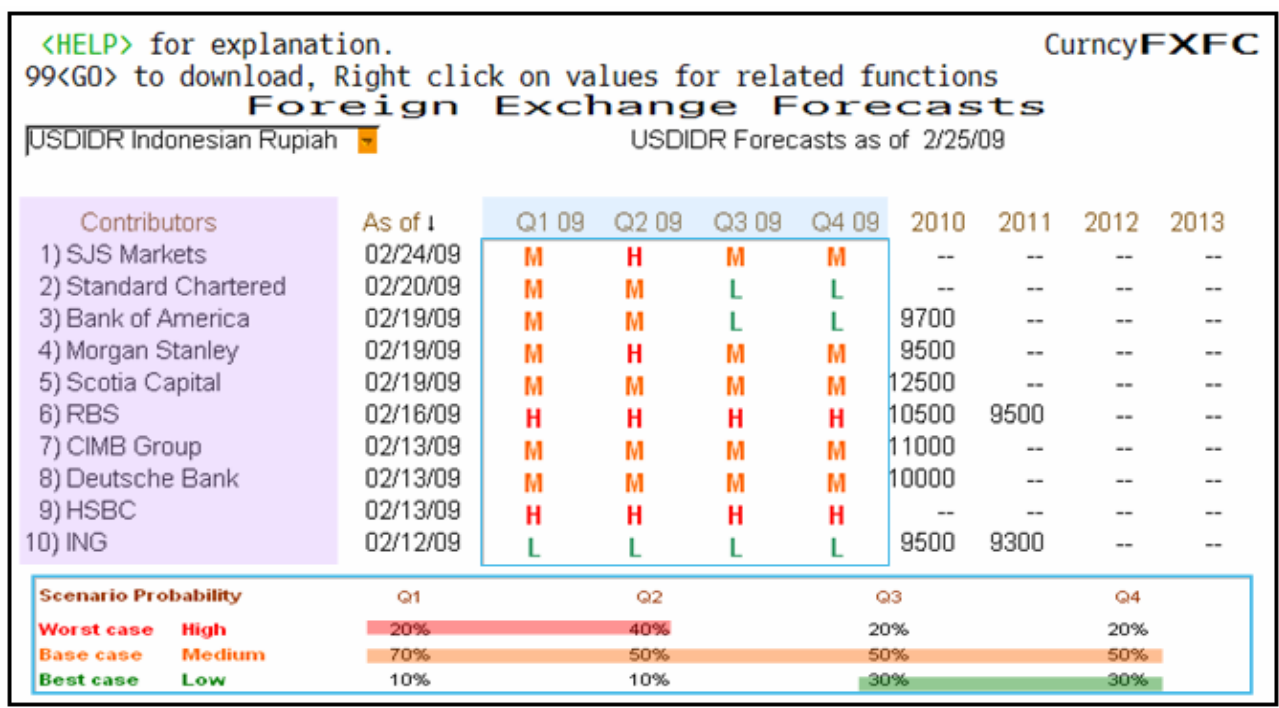

Even though exchange rate of IDR to USD remains above 11,000 referring to survey made by Bloomberg distributed by several major banks in the world, they are still optimist that IDR exchange rate will get stronger in some of the next quarters so that it can be put in the range.

Next, after the above valuing, we will combine them with the available products for every payment periods. Then, the result of the simulation in the form of profit/loss will be put into average weight in accordance to probability value in each scenario to calculate total monthly profit/loss or quarter payment based on each payment term to Pertamina and Turbomach. For product category see the following table: 
Table 9. Products Summary

\begin{tabular}{|c|l|l|}
\hline Items & \multicolumn{1}{c|}{ Description } & Type \\
\hline Product A & Permata Bank Forward (simulated) & Forward Contract 1 \\
\hline Product B & Permata Bank FX Option (simulated) & Option \\
\hline Product C & RBS Forward (simulated) & Forward Contract 2 \\
\hline Product D & Loan \& Deposit Mandiri Bank & Money Market A \\
\hline Product E & Loan Mandiri Bank \& Deposit RBS & Money Market B \\
\hline Product F & Loan BCA \& Deposit BCA & Money Market C \\
\hline
\end{tabular}

Next is the result of 2009 Payment Simulation using the 6 products forward in each payment term, which is displayed in the following illustration:

After we calculate all of the variable data that were obtained form the markets, we use them in our sensitivity analysis which consist of 16 payments terms, where 4 of them are Turbomach's and the remaining 12 payments are Pertamina. Here is the result on our simulation which determined the forecasted gain or loss off all the hedging products during those 2009 payments term. Please refer to the following table

Table 10. Conclusion Simulation 2009 Turbomach

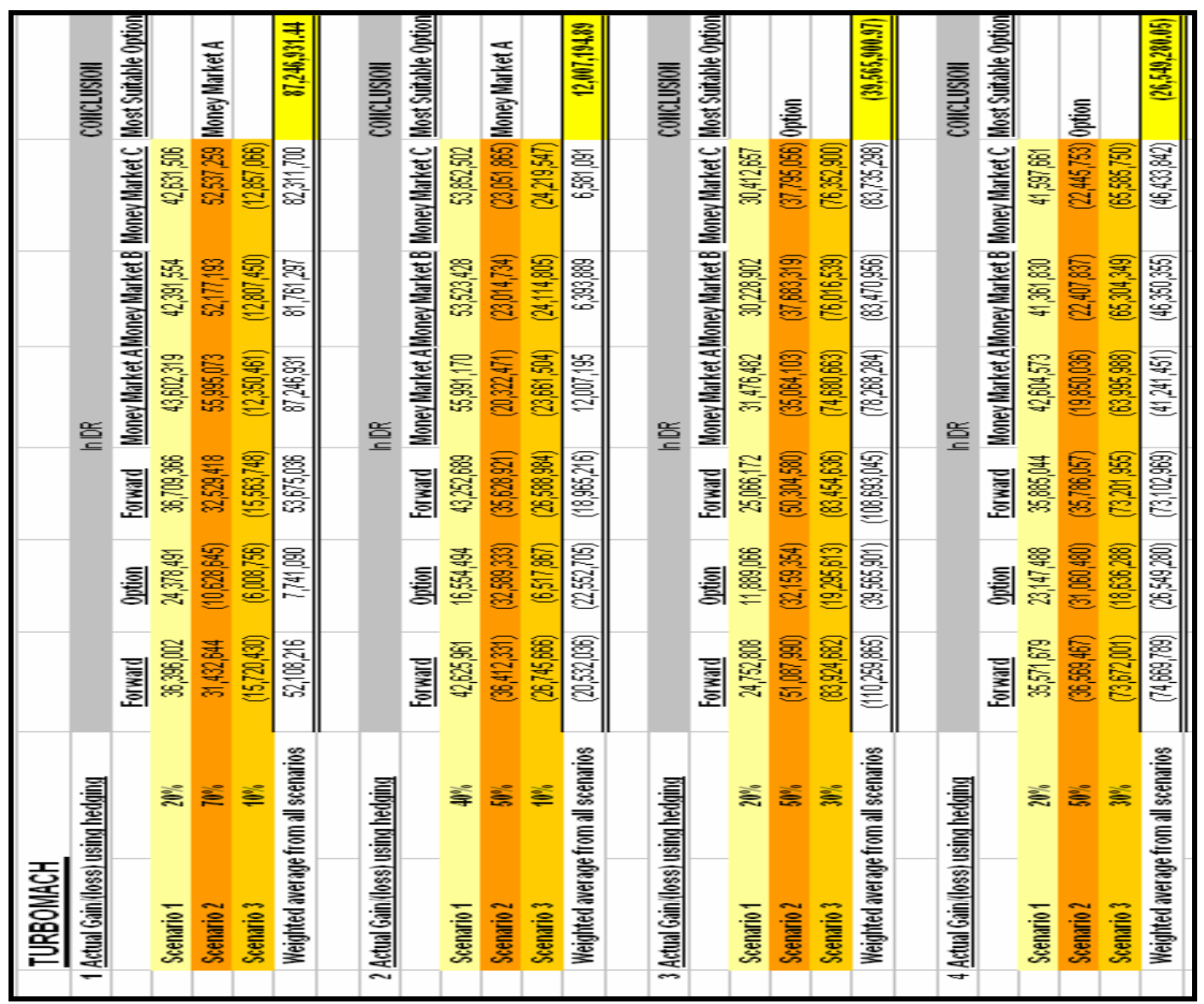


Table 11. Conclusion Simulation 2009 Pertamina

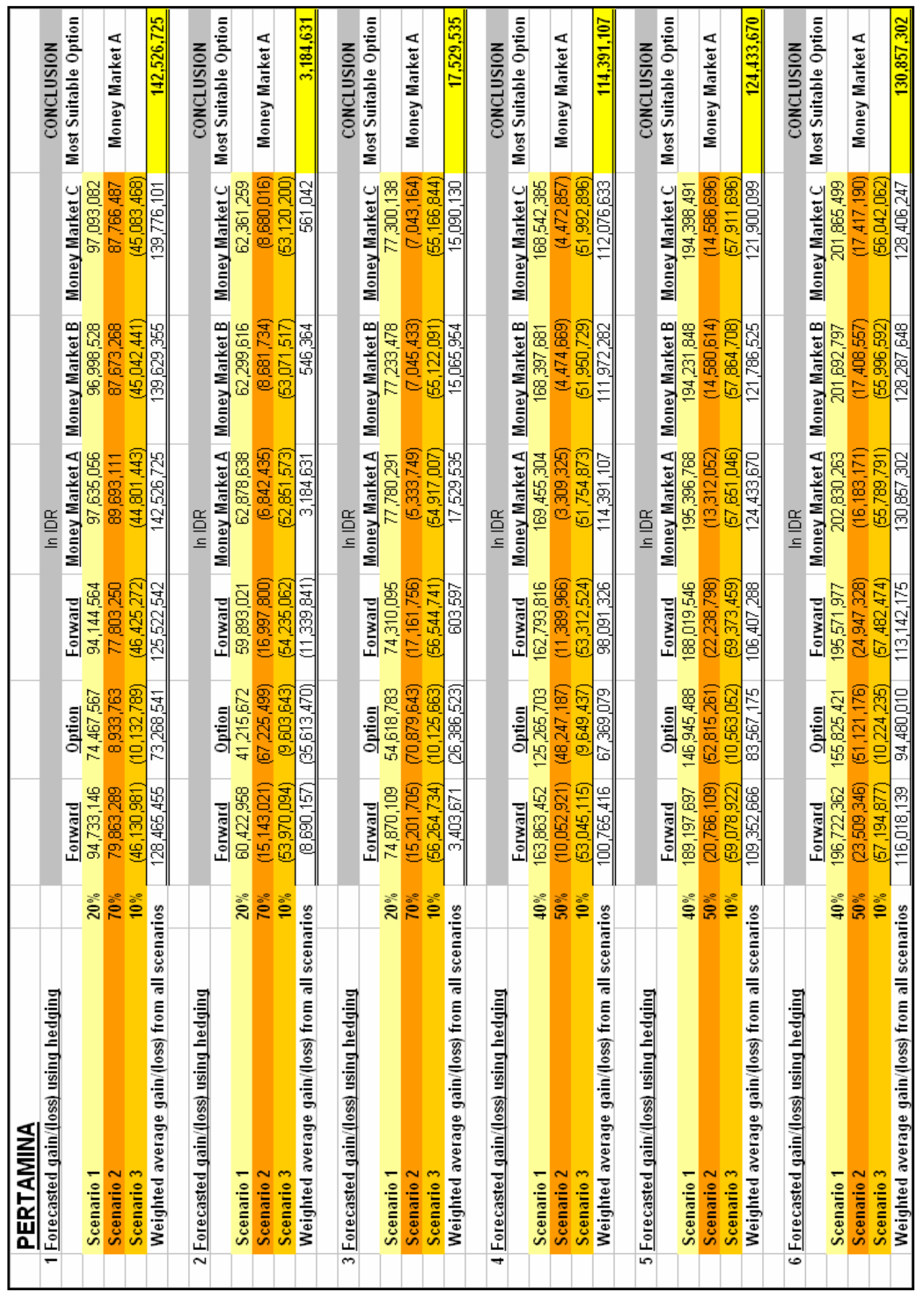


Table 12. Conclusion Simulation 2009 Pertamina (cont'd)

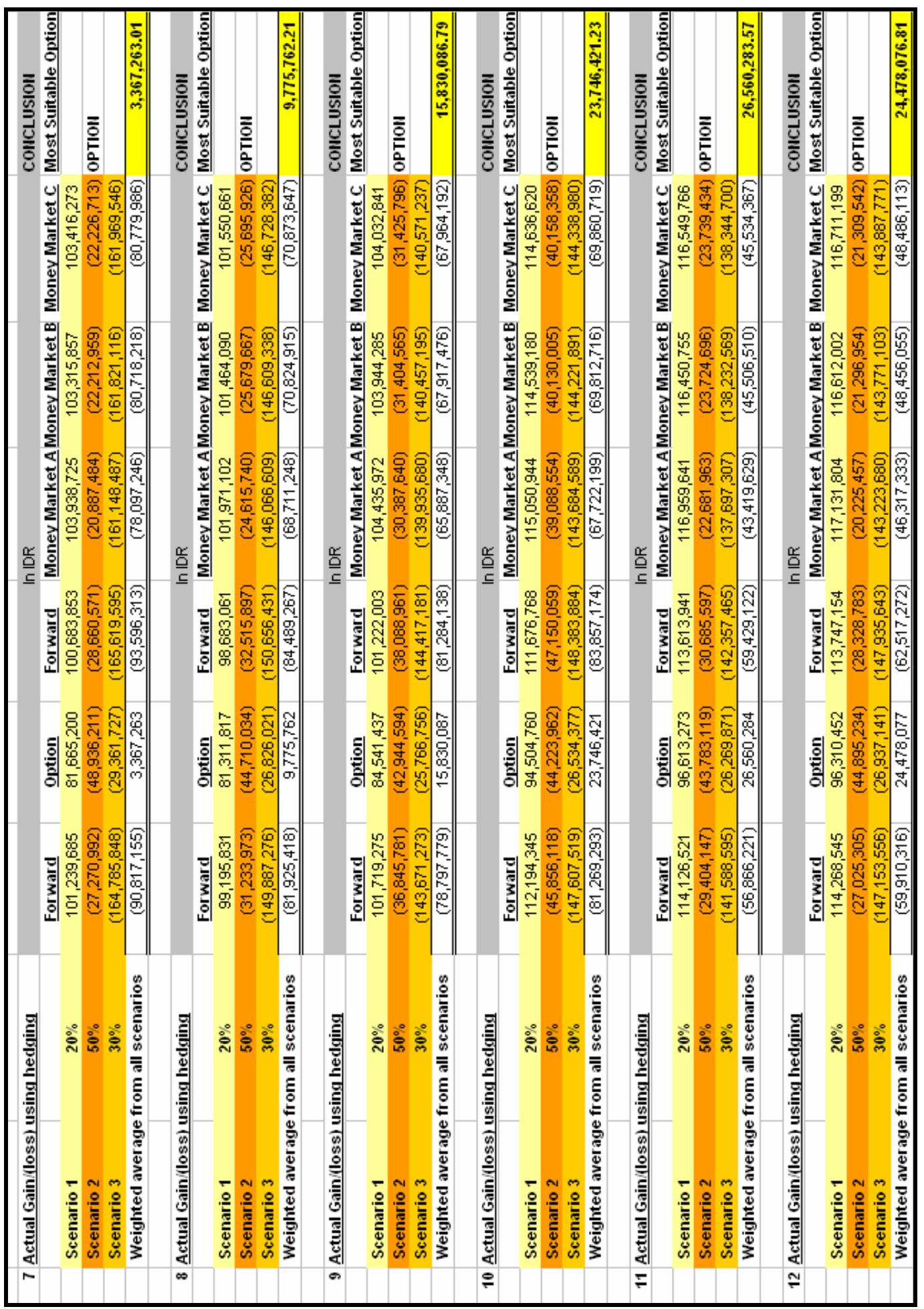




\section{CONCLUSION \& SUGGESTION}

\section{Conclusion}

Historical Period (2007 - 2008):

- $\quad$ PDP have transaction and economic exposure in doing their business.

- In order to mitigate the transaction and economic exposure which occurred during the 2007 and 2008 periods, then PDP have to implement some of the suggested hedging products like forward, option, money market hedge from Mandiri, Permata, BCA, \& RBS.

- By applying Hedging forward in 2007 and 2008 payments PDP will be able to save/avoid loss amounting to more than 1 billion rupiah compared to actual loss that is the result of open position and 795 million rupiah from applying Money Market Hedge.

- A Significant foreign currency fluctuation that occurred in a certain period such as happened between July 2008 to November 2008 when the IDR rate was drastically weakened by 3.622 points cost a big amount of forex loss which hit the PDP very own income.

Simulation Period (2009):

Based on the sensitivity analysis results in chapter IV, we can compare these three currency derivative products as below:

\begin{tabular}{|l|l|l|l|l|}
\hline $\begin{array}{l}\text { Currency } \\
\text { Derivative }\end{array}$ & $\begin{array}{l}\text { Obligation on } \\
\text { Settlement } \\
\text { Date }\end{array}$ & $\begin{array}{l}\text { Premium } \\
\text { Cost }\end{array}$ & Loss & $\begin{array}{l}\text { Uncertain } \\
\text { Future Foreign } \\
\text { Currency Cash } \\
\text { Outflow }\end{array}$ \\
\hline Forward & $\begin{array}{l}\text { Must } \\
\text { be executed }\end{array}$ & No & $\begin{array}{l}\text { Potentially } \\
\text { Higher } \\
\text { than Option }\end{array}$ & - \\
\hline Option & $\begin{array}{l}\text { Can } \\
\text { be executed } \\
\text { or not }\end{array}$ & Yes & $\begin{array}{l}\text { The flexibility } \\
\text { can minimize } \\
\text { the Loss }\end{array}$ & $\begin{array}{l}\text { Most } \\
\text { suitable }\end{array}$ \\
\hline $\begin{array}{l}\text { Money } \\
\text { Market } \\
\text { Hedge }\end{array}$ & $\begin{array}{l}\text { Must } \\
\text { be executed }\end{array}$ & No & $\begin{array}{l}\text { Same } \\
\text { as Forward }\end{array}$ & - \\
\hline
\end{tabular}

The use of Option FX for 2009 is a the most suitable choice if in the related periods of both worst case and best case probability is equal which means that there are possibility of both gain or loss. The privilege to be able to execute or not execute is the one advantage that were no possessed by the others. Meanwhile if worst-case and base case possibility is high, then forward or money market is the better option compare to FX option due to the fact that none of them are additional premium charged.

Based on the data we have collected both from third party professionals and international banks we conclude that IDR movement to USD will weaken until the end of quarter 2 of this 2009 and will be gradually stale and strengthened toward 4th quarter in 2009, 
so it is a wise option if PDP considers to use Hedge product available in Market during 2009 period.

\section{Suggestion}

Recommendation for PDP in implementing Hedging based on the result of sensitivity simulation analysis for 2009:

- The best way to implement the hedging simulation based on Bloomberg forecast is that in Q1 and Q2 of 2009, the market expectation is the IDR will grow weaker against the USD. Also based on our sensitivity analysis the results tend to generate forecasted gain on forex during these periods. For both of these reasons we suggest the company must do hedging instead of maintaining an open position.

- On the contrary for the Q3 and Q4 of 2009, as the market expectation during this period is the IDR will stand still if not getting stronger against the USD, as it was forecasted by Bloomberg, also based on our sensitivity analysis results which the products tend to generate a small amount of loss instead of gain on forex as it was in the Q1 and Q2, which can be lead into a conclusion that for this periods the Company can do hedging.

- Based on the six products in 2009 as presented in the previous Chapter, for monthly payment where time spread between invoice due date and payment date for July until December 2009, Permata FX Option is the best option based on our simulation and for January until June 2009 we recommend the company to use Money Market Hedge A from Bank Mandiri.

- For payment with three months tenure, we conclude that in the first and second quarter period, in which the expectation is that dollar will strengthen, then IDR Loan combination and USD Time Deposit from Bank Mandiri is the best option. Meanwhile in the third and fourth quarter where expectation toward rupiah is stable and tend to be a little bit strengthen, then Permata FX Option is a more reasonable option because of its possibility not to execute the contract if rupiah get stronger in the fourth quarter

- For payment process in 2009, PDP should try to revise their contract to Pertamina into IDR, since Pertamina is an Indonesian Company.

- To be able to maintain their A/R aging, particularly the one that is payment from PLN (State-owned Electricity Company), to enable them to manage cash in and cash out on time

\section{REFERENCES}

Adler, Michael., \& Dumas, Bernard. (1983). International portfolio choice and corporation finance: A synthesis, [Online] Available: http://ideas.repec.org/a/bla/jfinan/v38y1983i3p925-84.html [2009, Jan 2]

Bodie \& Merton (2000). Finance, International Edition. New Jersey: Prentice-Hall, , p.290

Bodnar, Gordon M., \& M.H. Franco Wong. (2001). Estimating exchange rate exposures: Issues in Model Structure, [Online] Available: www.nber.org/papers/w7497 - 16k 2000-01-01 [2009, Jan 1] 
Carter, David A., Christos, Pantzalis., \& Betty J. Simkins. (2003). Firmwide Risk Management of Foreign Exchange Exposure by U.S. Multinational Corporations, [Online] Available: http://www.coba.usf.edu/departments/finance/faculty/pantzalis/Firmwide\%20risk\%20 management....pdf $[2009$, Jan 1]

Doukas, John A., Patricia H. Hall., \& Larry H. P. Lang. (2001). Exchange Rate Exposure at the Firm and Industry Level, [Online] Available:

http://www.efmaefm.org/Exchange_rate_Lang+Hall+Doukas.pdf [2009, Jan 2]

Eiteman, David K., Stonehill, Arthur. I., \& Moffett, Michael H. (1994). Multinational Business Finance, $7^{\text {th }}$ edition. USA: Addison-Wesley, p. 92

Levi, Maurice D. (1990). International Finance, Second edition. Washington: Irwin McGrawHill, p.146, p.123.

Madura, Jeff. (2008). International Corporate Finance, Ninth Edition, China: Thomson South-Western, p.56, p.281, p.309.

Reilly, Frank K., Brown, Keith C. (2006). Investment Analysis and Portfolio Management, Eight Edition, Canada: Thomson South-Western, p. 807, p. 808, p. 811, p. 812, p. 848. 